\title{
Gender Differences in Attachment Styles Using Slovak Version of the Experiences in Close Relationships - Revised (ECR-R)
}

\section{Gabriela Rozvadský Gugová - Anton Heretik*}

\begin{abstract}
There is a vast amount of literature on similarities and differences of women and men experiencing (close) relationships and using different strategies for coping with daily stress and significant life events. Western folk psychology expects women to be generally more anxious and men to be more avoidant when solving close-relationship conflicts and experiences in long term relationships. We used the Experiences in Close Relationships - Revised (ECR-R) questionnaire that is based on the Attachment-style theory distinguishing four distinct attachment styles - secure, anxious/ambivalent, disoriented/disorganized and avoidant.
\end{abstract}

Keywords: experiences in Close Relationships - Revised (ECR-R), anxiety, avoidance, coping.

\section{Introduction}

People have to cope with daily pressure of their surroundings, which is often a stressful experience. There is a vast amout of literature on the topic of coping with stress and the related phenomena. Many authors (e.g., Lazarus, 1966; Amirkhan, 1990) discuss the problems of coping strategies in terms of effectiveness, appropriateness, success, and the like. Two biologically based types of coping strategies are generally recognized escape (flight) and aggression (fighting) techniques. Based on the research results, the avoidance strategy was later added (Heretik, jr. et al, 2008). J. H. Amirkhan (1990) offered the following basic coping strategies: the instrumental strategies aimed at the problem, the search strategy of social support, turning to other people and the strategies of avoidance, withdrawal, and escape.

Individuals generally prefer one type of coping with stress and there is significant interpersonal variability. On the other hand, it seems that there exist group differences based on gender. In stressful situations women tend to react with fear and retreat and

* Gabriela Rozvadský Gugová, Dubnica Technological Institute, Dubnica nad Váhom, Slovakia; gugova@dti.sk

Anton Heretik, Dubnica Technological Institute, Dubnica nad Váhom, Slovakia; heretik@dti.sk 


\section{Acta Technologica Dubnicae}

volume 1, 2011, issue 2

they more often turn to their close social surroundings. They also speak more openly about the emotional aspects of demanding situations. Men, in general, are oriented towards solving their problems on their own, and they are more "instrumentally" focused (towards solving the problem-oriented strategies and relieving the stress through the activities like sports or even drinking alcohol). A. Heretik jr. et al. (2008) found significant gender differences in strategies of coping with stress and difficult life situations based on the data from an epidemiological study of selected anxiety disorders and trait-anxiety called EPIA ( $\mathrm{N}=1251$, Novotný et al., 2006). Women coping with stress turned significantly more often towards their close relatives and the priests. Men more often reported sport, hobbies but also drinking alcohol as their strategy to relieve stress. It also seems that in the relationship between the attachment and the coping strategies, there are even gender differences in coping with stressful events.

The Theory of Attachment Styles is based on the presence of stable longitudinal patterns of expectations, needs, affecting regulation strategies and social behavior that can be traced to early childhood experiences of the attachment to significant persons mostly parents. The author of a classical version of the attachment theory is J. Bowlby (1969). A significant contribution for the theory from the psychometric perspective was brought up by $\mathrm{M}$. Ainsworth and significant revisions and orientation towards the adult attachment style was conducted by P. R. Shaver and his colleagues (Mikulincer Shaver, 2007). The cross-cultural studies showed that the attachment styles are valid in cultures that differ from the Western world (Young-Sun et al., 2008). The research also shows that both the attachment style and coping tend to be the stable long-term patterns of behavior independent from the actual mood or trait-anxiety (Picardi et al., 2005; Mikulincer - Shaver, 2007).

R. C. Fraley, N. G. Waller and K. A. Brennan's (2000) ECR questionnaire, underwent a detailed psychometric analysis using the item response theory, resulting in a revised version of the original questionnaire, which is now known as the ECR-R (Experiences in Close Relationships - Revised). Both versions contain 20 items. L. Dvorská (2008) used the ECR-R questionnaire for examining the relationship between the emotional attachment in romantic relationships and coping strategies of adults. At present the ECR-R is considered to be a tool with sufficiently proven psychometric properties (Bieščad - Hašto, 2010).

The goal of the present study is to analyze the data based on ECR-R reports about the attachment styles towards romantic partners of 920 Slovak adult respondents with the focus on gender differences. In the discussion we try to relate our findings to the findings of some foreign authors and to the topic of coping strategies of men and women. 


\section{Acta Technologica Dubnicae}

volume 1, 2011, issue 2

\section{Methodology}

We used the translation of the experiences in Close Relationships-Revised (ECR-R) to the Slovak language (Bieščad - Hašto, 2010). In the survey there was a total of 920 respondents, comprising 428 men and 492 women ranging in age from 18 to 55 years $(\mathrm{M}=30.20, \mathrm{SD}=8.65)$, all being secondary school graduates of Czech and Slovak nationality. The administration of the test was conducted from September to December 2010 in groups of 50 to 100 respondents. Further description of the sample of respondents and ECR-R can be found in Rozvadský Gugová (2010). For the administration a paper sheet questionnaire was used. The respondents filled in the data on a pre-printed sheet of A4 paper with the questions. The time limit was not set. The respondents were able to adapt well to a group of 100 people and reported no problem with time.

In the first part of the administration, the respondents were given instructions on the type and purpose of the questionnaire, in the second part the paper sheets were provided to each participant. In the next section, as the administrator verified that all respondents have completed the basic data in anamnestic part, a short briefing of ECR$\mathrm{R}$ was offered.

\section{Results}

Gender and scores on the attachment-related anxiety and attachment-related avoidance

We found statistically significant differences in relationship between gender and score on both scales. Women scored significantly higher on Anxious scale (t-test (493.427) $=$ 2.272, $\mathrm{p}=0.006, \mathrm{~d}=0.15)$ - Table 1 . Men scored significantly higher on Avoidant scale $(\mathrm{t}$-test $(493.427)=-2.427, \mathrm{p}=0.015, \mathrm{~d}=0.13)-$ Table 1 .

\begin{tabular}{|l|l|l|l|l|}
\hline ECR-R Scales & Gender & N & M & SD \\
\hline \multirow{2}{*}{$\begin{array}{l}\text { Anxiety Scale } \\
\text { Score }\end{array}$} & Women & 493 & 58.69 & 17.74 \\
\cline { 2 - 5 } & Men & 427 & 55.56 & 16.90 \\
\hline \multirow{2}{*}{$\begin{array}{l}\text { Avoidance } \\
\text { Scale Score }\end{array}$} & Women & 493 & 44.63 & 15.11 \\
\cline { 2 - 5 } & Men & 427 & 47.00 & 14.49 \\
\hline
\end{tabular}

Table 1 Gender differences in Attachment-related anxiety and Attachment-related avoidance of ECR

$\mathrm{N}=$ Number of participants, $\mathrm{M}=$ Mean, $\mathrm{SD}=$ Standard deviation 
Marital status and scores on Attachment-related anxiety and Attachment-related avoidance

In the whole group we have not found any statistical differences between the marital status and the scores on both scales (for marital status and Attachment-related anxiety score ANOVA, $\mathrm{F}=2.479, \mathrm{p}=0.060$, ETA $=0.110$ ) and for marital status and Attachment-related Avoidance score, ANOVA, $\mathrm{F}=0.051, \mathrm{p}=0.985$, ETA $=0.16$ ) Table 2.

\begin{tabular}{|l|l|l|l|}
\hline Marital status & \multicolumn{2}{|l|}{ Anxiety Scale Score } & Avoidance Scale Score \\
\hline Single & M & 58.77 & 45.14 \\
& N & 355 & 355 \\
& SD & 18.52 & 14.53 \\
\hline Married & M & 54.92 & 45.52 \\
& N & 212 & 212 \\
& SD & 17.31 & 15.85 \\
\hline Divorced & M & 53.82 & 45.77 \\
& N & 39 & 39 \\
& SD & 17.32 & 15.75 \\
\hline Total & M & 57.11 & 45.32 \\
& N & 606 & 606 \\
& SD & 18.10 & 15.05 \\
\hline
\end{tabular}

Table 2 Marital status and in Attachment-related anxiety and Attachment-related avoidance of ECR-R

*There was only one person in category "Widowed" and this group was excluded from the analysis.

Divided sample based on gender showed significant relationship between marital status and score on Anxiety scale (ANOVA, F $=5.554, \mathrm{p}=0.004$, ETA $=0.201$ ) - Table 3 . Single men scored significantly higher than other marital groups (t-test $(166.85)=$ $3.052, \mathrm{p}=0.003, \mathrm{~d}=0.41$ ) - the effect that did not show in the group of women.

\begin{tabular}{|l|l|l|l|l|}
\hline \multirow{3}{*}{ Gender } & \multirow{2}{*}{ Marital status } & Anxiety Scale Score & Avoidance Scale Score \\
\hline \multirow{4}{*}{ Women } & \multirow{3}{*}{ Single } & $\mathrm{M}$ & 58.69 & 42.2 \\
\cline { 2 - 5 } & $\mathrm{N}$ & 188 & 188 \\
\cline { 2 - 5 } & \multirow{3}{*}{ Married } & $\mathrm{SD}$ & 18.37 & 14.28 \\
\cline { 3 - 5 } & & $\mathrm{N}$ & 126.94 & 45.75 \\
\cline { 3 - 5 } & & $\mathrm{SD}$ & 18.24 & 127 \\
\hline
\end{tabular}




\begin{tabular}{|c|c|c|c|c|}
\hline & & $\mathrm{M}$ & 55.83 & 46.13 \\
\hline & Divorced & $\mathrm{N}$ & 24 & 24 \\
\hline & & \begin{tabular}{|l} 
SD \\
\end{tabular} & 18.3 & 14.99 \\
\hline & & $\mathrm{M}$ & 57.84 & 43.82 \\
\hline & Total & $\mathrm{N}$ & 340 & 340 \\
\hline & & SD & 18.26 & 15.27 \\
\hline & & $\mathrm{M}$ & 59.07 & 48.46 \\
\hline & Single & $\mathrm{N}$ & 166 & 166 \\
\hline & & SD & 18.61 & 14.17 \\
\hline & & $\mathrm{M}$ & 51.91 & 45.19 \\
\hline & Married & $\mathrm{N}$ & 85 & 85 \\
\hline & & SD & 15.44 & 14.77 \\
\hline & & $\mathrm{M}$ & 50.6 & 45.2 \\
\hline Men & Divorced & $\mathrm{N}$ & 15 & 15 \\
\hline & & SD & 15.67 & 17.42 \\
\hline & & $\mathrm{M}$ & 56.3 & 47.2 \\
\hline & Total & $\mathrm{N}$ & 266 & 266 \\
\hline & & SD & 17.8 & 14.58 \\
\hline
\end{tabular}

Table 3 Gender differences in marital status and in Attachment-related anxiety and Attachment-related avoidance of ECR-R

Age and scores on Attachment-related anxiety and Attachment-related avoidance

Age correlated negatively with the score on Anxiety Scale $(r=-0.101, p=0.02)$ and positively on the Avoidant scale $(\mathrm{r}=0.075, \mathrm{p}=0.023)$. Results were statistically significant, but correlations are marginal. Gender did not influence the direction or robustness of these results.

\section{Discussion}

Analysing the differences in the attachment style we found that women scored significantly higher on attachment-related anxiety and men significantly higher on attachment-related avoidance. This is in correspondence with the existing literature (Alonso-Arbiol et al, 2007; Mikulincer - Shaver, 2007) and also with typical western folk psychology expectations. Metaanalysis of 100 studies with attachment style measures showed gender differences in the same direction as our study (Del Giudice, 2011).

We can compare our results with findings of Greek authors Koskina and Giovazolias, 2010. Participants were nonclinical male $(n=100)$ and female $(n=381)$ university 


\section{Acta Technologica Dubnicae}

volume 1, 2011, issue 2

students. Other Greak study of Tsagarakis, Kafetsios, and Stalikas (2007), present the ECR-R which was used to measure romantic attachment. They have demonstrated good validity and reliability (factor structure, criterion, convergent validity, internal consistency, and test-retest reliability). Moreover, they reported a high reliability ( $\alpha=$ 0.91 for each dimension) and a moderate correlation $(r=0.43)$ between the two dimensions (anxiety and avoidance).

In case, (Koskina and Giovazolias, 2010) the reliability was $\alpha=0.89$ for the total ECRS-R ( $\alpha=0.88$ and 0.86 , for the subscales anxiety and avoidance, respectively). The two subscales had a moderate correlation $r=0.31(p<0.01)$. Independentsamples $t$ test revealed significant gender differences in romantic attachment. Men scored significantly higher on the ECRS-R, $(479)=3.07, p<0.05$. This difference was attributed to the avoidance dimension, with men reporting being more avoidant, $t(479)=4.27, p<0.001$. In our case we had moderate correlation $\mathrm{r}=0.365^{* *}$, correlation is significant at the 0.01 level (2-tailed) for the subscales anxiety and avoidance.

Finally, it should be noted that the attachment style as a stable pattern is not only connected to relationship with a parent or a romantic partner. The preferred stable personal attachment style can be found also in school environment in relationship with a teacher and peers (Al-Yagon - Mikulincer, 2004). This has direct implications also for educational process. There are some limitations of the presented study which should be considered. The participants were mostly young people with high percentage of them being in early 20's of their age. Quite large percentage (34.1\%) had not stated their marital status which could skew relationship between the scores for Attachmentrelated anxiety and Attachment-related avoidance. On the other hand, the analyses of the relationship between the mentioned variables were based on a group of more than 600 participants.

\section{Conclusions}

Analyzing the differences in attachment style we found that women scored significantly higher on attachment-related anxiety and men significantly higher on attachment-related avoidance. This reflects the general tendency towards experiencing close relationships, but based on other studies it has similar impact on other relationships - like peer relationships or teacher-student relationship. The study found an interesting result on marital status and attachment style where single men scored significantly higher on attachment-related anxiety scale of ECR-R. Next we focus on the item analysis of ECR-R in relationship to gender and marital status and in future 
we plan to do some methodological study on psychometric qualities of ECR-R based on the obtained sample.

\section{References}

AL-YAGON, A. - MIKULINCER, M.: Socioemotional and Academic Adjustment Among Children with Learning Disorders: The Mediational Role of AttachmentBased Factors. In The journal of special education, vol. 38, 2004, no. 2, pp. 111123.

ALONSO-ARBIOL, I. - BALLUERKA, N. - SHAVER, P. R.: A Spanish version of the Experiences in Close Relationships (ECR) adult attachment questionnaire. In Personal Relationships, vol. 14, 2007, pp. 45-63.

AMIRKHAM, J. H.: A Factor Analytic Derived Measure of Coping. The Coping Strategy Indicator. In Journal of Personal and Social Psychology, vol. 59, 1990, no. 5, pp. 1066-1074.

BIEŠČAD, M. - HAŠTO, J.: Diagnostikovanie typov vzt'ahovej väzby (attachment) $\mathrm{v}$ dospelosti s použitím nástrojov dostupných v našich podmienkach. (Diagnosing of attachment types in adulthood using available tools). In Psychiatrie, vol. 14, 2010, no. 2, pp. 68-74.

BOWLBY, J. Attachment. Attachment and Loss. Vol. I. London: Hogarth, 1969.

FRALEY, R C., WALLER, N. G., BRENNAN, K. A.: An item-response theory analysis of self report measures of adult attachment. Journal of Personality and Social Psychology, vol. 78, 2000, no. 2, pp. 350-356.

DEL GIUDICE, M.: Sex Differences In Romantic Attachment: A Meta-Analysis. In Personality \& Social Psychology Bulletin, vol. 37, 2011, no. 2, pp. 193-214.

DVORSKÁ, L.: Vztah mezi citovou vazbou v romantických vztazích a strategiemi zvládání v adolescence. In: Heller, D. Charvát, M. Sobotková, I. (Eds.) Psychologické dny 2008: Já \& my a oni. Brno: VšpS MU a ČMPS, pp. 10

HERETIK, A., jr. - HERETIK, A., sr. - NOVOTNÝ, V. - PEČEŇÁK, J. RITOMSKÝ, A.: Úzkostlivost' a zvládacie stratégie: analýza výsledkov zo štúdie EPIA. (Trait-Anxiety and coping strategies: Analysis of result based on EPIA study). In Psychologica 39 (CD ROM). Bratislava : Stimul, 2008, pp. 256265.

KOSKINA, N. - GIOVAZOLIAS, T.: The Effect of Attachment Insecurity in the Development of Eating Disturbances across Gender: The Role of Body Dissatisfaction. In The Journal of Psychology, vol. 144, 2010, no. 5, pp.449-471.

LAZARUS, R. S.: Psychological Stress and the Coping Process. New York: McGrawHill, 1966.

MIKULINCER, M. - SHAVER, P. R.: Attachment in Adulthood Structure, Dynamics, and Change. New York: Guilford Press, 2007. 
NOVOTNÝ, V. - HERETIK, A., sr. - HERETIK, A., jr. - PEČEŇÁK, J. RITOMSKÝ, A.: EPIA - Epidemiológia vybraných úzkostných porúch na Slovensku. (EPIA - Epidemiology of Selected Anxiety Disorders in Slovakia). Nové Zámky: Psychoprof, 2006.

PICARDI, A. - CAROPPO, E. - TONY, A. - BITETTI, D. - Di MARIA, G.: Stability of Attachment-Related Anxiety, Avoidance and Their Relationship with FiveFactor Model and Psychobiological Model of Personality. In Psychology and Psychotherapy: Theory, Research and Practice, vol. 78, 2005, pp. 327-345.

ROZVADSKÝ GUGOVÁ, G.: Coping Strategies in Conflict Situations (Anxiety and Avoidance). In University Review, Health Care, vol. 4, 2010, no. 54, p. 54.

TSAGARAKIS, M. - KAFETSIOS, K. - STALIKAS, A.: Reliability and validity of the Greek version of the Revised Experiences in Close Relationships (ECR-R) measure of adult attachment. In European Journal of Psychological Assessment, vol. 23, 2007, pp. 47-55.

YOUNG-SUN, L. - GROSSMAN, J. - KRISHNAN, A.: Cultural Relevance of Adult Attachment: Rasch Modeling of the Revised Experiences in Close Relationships in a Korean Sample. In Educational \& Psychological Measurement, vol. 68, 2008, 5, pp. 824-844. 